J. Perinat. Med. 13 (1985) 265

\title{
The potential use of nuclear magnetic resonance imaging in preg- nancy
}

\author{
F. W. Smith
}

Department of Nuclear Medicine, Aberdeen Royal Infirmary, Aberdeen, Scotland, U. K.

\section{Introduction}

Imaging of the human body using the phenomenon of nuclear magnetic resonance (NMR) has been introduced in to a number of centres in the past 3-4 years since the first clinical trial of the technique was started in 1980 at the University of Aberdeen [4, 12, 13]. During this time it has been shown to be of diagnostic value in studying the brain [1], abdomen $[14,15]$, and in pediatric practice [11, 8], more recently its potential for examining the normal fetus in-utero has been demonstrated $[7,16,17]$ as well as abnormal pregnancy [18].

The technique is free from hazard to both mother and fetus, relying not on ionising radiations to produce an image, but radiofrequency radiation which is harmless. The images, being made up of information directly obtained from hydrogen atoms in the body, are more tissue specific than X-ray CT images, which they closely resemble. The tissue specificity of the technique is related to the relationships of water to protein within different tissues, and with further research may be able to give a non-invasive measure of body water.

At present the potential of this new imaging system is being explored in pregnancy. The preliminary findings indicate that its images are more informative than ultrasound, but because the examination time is about four times longer

\section{Curriculum vitae}

Francis WILliam SMITH was born 1943 in Colchester, England. He grew up in Zimbabwe where he was educated at Prince Edward School, Harare. He studied medicine at the University of Aberdeen from which he graduated in 1970. He successively studied radiology at Aberdeen Royal Infirmary and the

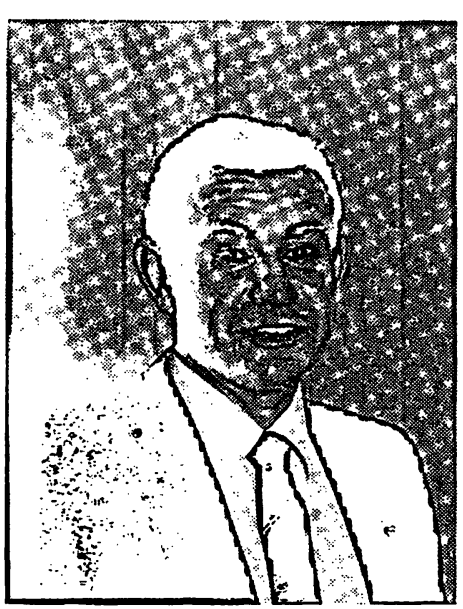
Hospital for Sick Children in Toronto. He is Consultant in nuclear medicine at Aberdeen Royal Infirmary and Coeditor of Magnetic Resonance Imaging.

than for ultrasound, it is not suggested that it replace ultrasound for the routine examination of the fetus. It is more likely to become a useful method for studying abnormal pregnancy.

\section{Physical principles}

The NMR phenomenon and the methods used for obtaining images with it are quite complex. Some of the phenomena can be explained only by quantum mechanics, but those relevant to a basic comprehension of the technique and sufficient for the appreciation of its applications in medicine may be understood using the principles of mechanics and magnetism. 
To understand the underlying phenomenon, we should return to basic physics and chemistry. Each atomic nucleus is made up of nucleons, that is, protons and neutrons (the one exception to this is the hydrogen atom, which consists of a single proton). These nucleons rotate or "spin" about their axes. When pairs of protons or pairs of neutrons exist in the nucleus, they align in such a way that their spins cancel each other out, and such pairs are of no interest to us for this discussion. However, when a nucleus contains an unpaired proton or neutron or both, the nucleus will have a net spin (i. e. it will rotate on its axis). Because the nucleus has an electric charge, the spin corresponds to a current flowing about the spin axis; this in turn generates a magnetic field. The nucleus may, therefore, be considered a small bar magnet spinning on its axis.

In normal circumstances, these nuclei spin while pointing in a random direction, but when placed in a uniform static magnetic field, a portion of them will align with the field's lines of force. These spinning nuclei behave like tiny spinning tops or gyroscopes, which, if tipped away from the vertical axis, will rotate about this axis in a motion known as precession. To make the nuclei precess around their axes, a smaller external electromagnetic field must be applied. This applied electromagnetic radiation must match the natural precessional frequency of the nuclei in the sample, hence the term nuclear magnetic resonance. This resonance frequency, often known as the LARMOR frequency, is related mathematically to the externally applied magnetic field. The frequency is equal to the strength of the field measured in tesla $(T)(1$ tesla $=10,000$ gauss $)$ multiplied by the gyromagnetic frequency, which is unique for each species of nucleus. Thus, for hydrogen protons in a 1-tesla field, the resonance frequency is $42.57 \mathrm{MHz}$. In the same field, the resonance frequencies of ${ }^{31} \mathrm{P}$ and ${ }^{23} \mathrm{Na}$ are 17.24 and $11.26 \mathrm{MHz}$ respectively. These frequencies are far below those of X-rays and visible light, and are too weak to do any biological damage.

By choosing relevant frequencies, one can tune in to specific nuclei and observe their reactions.
So far, all medical NMR images have been obtained with resonances from hydrogen nuclei $\left({ }^{1} \mathrm{H}\right)$. This is because hydrogen is not only abundant in the body, but also has a higher intrinsic NMR sensitivity than do other nuclei. ${ }^{31} \mathrm{P}$ is found in concentrations too low to image at present, but it is in sufficient quantity to be measured spectroscopically.

Several methods are available that use the NMR signal for image production. By manipulation of smaller electromagnetic fields around the static field, a number of different imaging techniques have been developed. Whether they use the projection reconstruction method used in X-ray CT or the sensitive-point, sensitive-line, steady-state free precession, or spin-warp methods, they all rely on measuring proton density and proton-relaxation times (1 and $\mathrm{T}_{2}$ ). Each of the different methods produces a slightly different type of image. Some are pure proton density, others are pure $T_{1}$ and $\mathrm{T}_{2}$.

The different methods all rely on pulsed radiofrequency radiations of known strength, but they vary in the length of the pulse applied to manipulate the protons. The pulse sequence may also be varied (i. e. the intervals between pulses may be varied) to obtain useful data for image construction. The principles of the image production are simply explained. When the length of the applied radiofrequency is increased (so that the angle of precession is rotated through $90^{\circ}$ and then stopped), the protons decay or relax, emitting the radiation they absorbed when they moved through $90^{\circ}$. The strength of this signal is a measure of the proton density of the section being examined. If a longer excitation pulse is used, the angle of precession can be moved through $180^{\circ}$ (i. e. the spins are inverted). When the radiation is measured (specifically, the length of time taken for the protons to return to equilibrium), the proton spin-lattice relaxation time or $T_{1}$ is measured. $T_{1}$ varies from substance to substance, this variation depending on the relationship of the hydrogen atoms to their surroundings or molecular lattice. Short relaxation times exist where water (rich in hydrogen) is 
closely bound to proteins such as are found in muscle or liver, or in fat, which is also rich in hydrogen. Long relaxation times occur in fluids such as urine and cerebrospinal fluid. Depending on the amounts of free and bound water in tissues, the $T_{1}$ will vary, allowing for good tissue discrimination and evaluation. The other important relaxation time is $T_{2}$, or the spin-spin relaxation time. Its magnitude depends on the magnetic interaction between nuclear spins during the relaxation of decay period. It therefore makes a significant contribution to the decay of the NMR signal. It may be measured specifically by applying a string of $180^{\circ}$ pulses and recording the decaying emitted signal. As mentioned earlier, a number of different types of image may be produced. Proton density may be displayed as a pure calculated proton density map or used as the major signal in saturation recovery images. $T_{1}$ may similarly be displayed as a pure calculated value or as the major component of inversion recovery images. $T_{2}$ measurement is used as the main constituent of spinecho images. The foregoing description is, of necessity, simple; for a more detailed but nonetheless basic description, a number of articles may be consulted $[9,10]$.

No reports of any adverse effect from the technique have been reported. There are three areas of potential hazard; the static magnetic field, the rapidly changing electro-magnetic fields and the radiofrequency radiation. The safe limits for all three are well above the levels employed by all currently available Magnetic Resonance Imagers. The guidelines for imaging published by the British National Radiological Protection Board lay down the safe limits and indicate the patients with cardiac pacemakers and ferromagnetic implants should be excluded. Whilst no evidence of any mutogenic effect has been reported in cell culture [2], dividing bacteria [20] or goats [5] it is advised that pregnancy in the first trimester should not be imaged unless that pregnancy is going to be terminated. However, in the second and third trimesters, when organogenesis is complete, no contra-indication to imaging exists.

\section{Patients and methods}

The imaging of pregnant patients in Aberdeen began in 1982 when a series of first trimester pregnancies were examined prior to therapeutic termination of pregnancy to assess the feasibility of using NMR imaging [16]. In 1984 following approval by the Ethical Committee and complying with the guidelines recommended by the National Radiological Protection Board [19], imaging of second and third trimester pregnancy was started. During the first year of this study 70 pregnant volunteers had a total of 105 examinations each consisting of one sagittal and multiple transaxial sections taken at $4 \mathrm{~cm}$ intervals.

All examinations were performed using the University of Aberdeen NMR imager which uses a low field strength resistive magnet of $0.08 \mathrm{~T}$ (800 gauss) producing a resultant frequency of $3.4 \mathrm{MHz}$ for the hydrogen proton. The 'spin-warp' method of imaging is employed, using a pulse sequence of interleaved saturation recovery and inversion recovery pulses. $\left(T_{R}=1000 \mathrm{~ms}, T_{I}=200 \mathrm{~ms}\right)$. The inversion recovery pulse is preceeded by Adiabatic Fast Passage. Fcr those requiring a more detailed description, the technique is fully documented elsewhere $[3,4,6]$. The data to produce each set of images of a section are collected in just over 4 minutes (256 seconds); each section may be either 1.2 or $1.5 \mathrm{~cm}$ thick. These are interpolated to $256 \cdot 256$ for final presentation on a greyscale video display unit.

The principal aims of the study were to evaluate how well NMR imaging demonstrated maternal and fetal anatomy, and to determine normal fetal and maternal tissue characteristics my measuring $T_{1}$ at various stages of normal and complicated pregnancies.

\section{Observations}

The most striking feature of NMR images is the clarity with which different soft tissue structures are demonstrated. Unlike ultrasound and $\mathrm{X}$-ray CT, no artefacts from bone or bowel gas occur and maternal anatomy is invariably well 
demonstrated. Good definition of superficial tissues such as fat and muscle, as well as deep structures including bone, placenta, myometrium and cervix are demonstrated. These are best demonstrated on the calculated $T_{1}$ images, where the contrast between the different tissues is best appreciated and structures with a short $T_{1}$ value, such as fat, appear dark grey, those with intermediate values appear light grey and those with long $T_{1}$ relaxation time values, usually fluids, appear white. The proton density
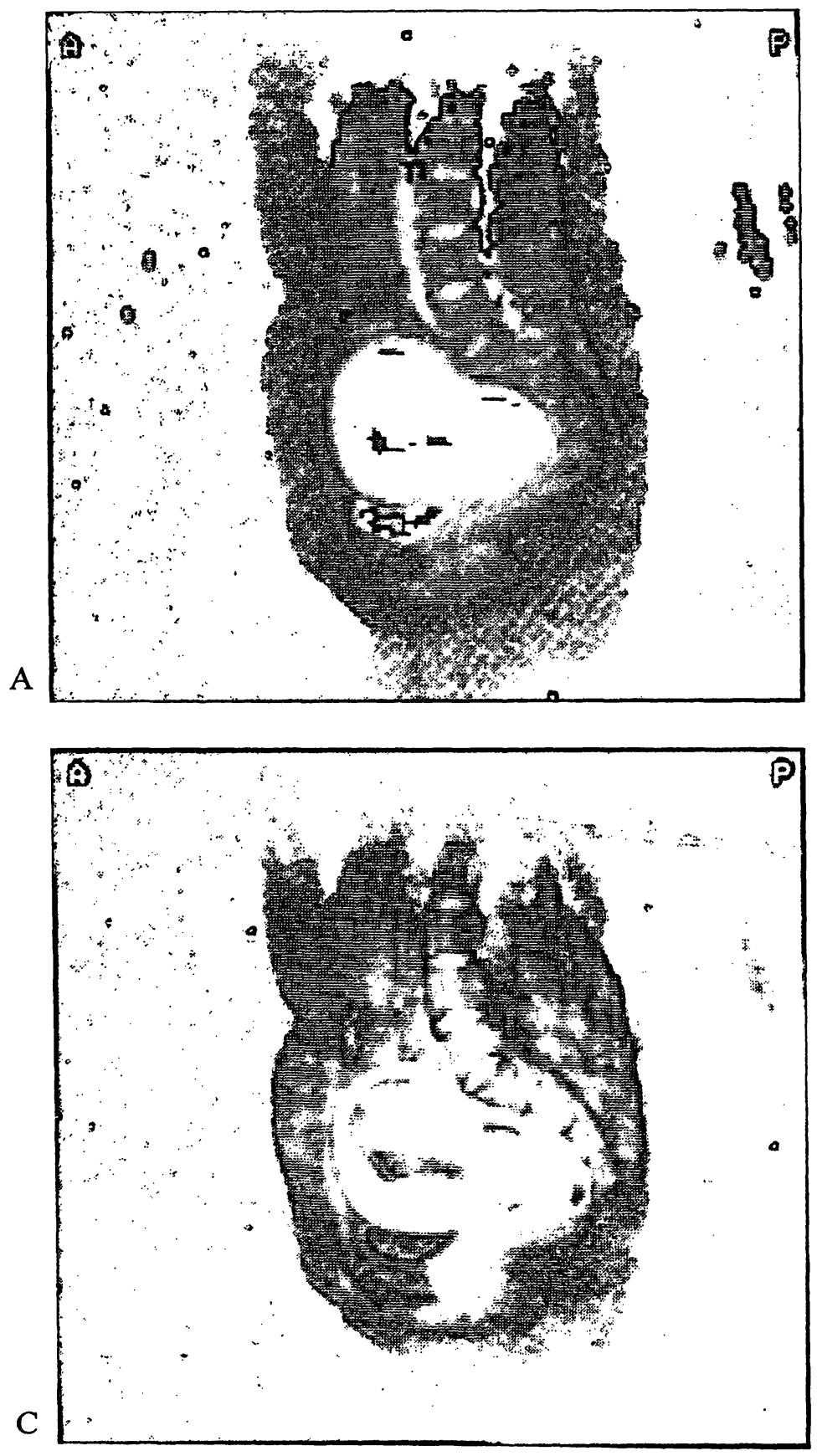

images are relatively featureless but are important because of the good spatial resolution seen at soft tissue/fluid and soft tissue/bone interfaces. The inversion recovery images demonstrate fat as white and are the most useful for measuring fat thickness. A "Difference" (D) image is available which is produced by subtracting the inversion recovery signal from the proton density signal giving an image with the contrast resolution of the calculated $\mathrm{T}_{1} \mathrm{im}$ age to give a useful general image.

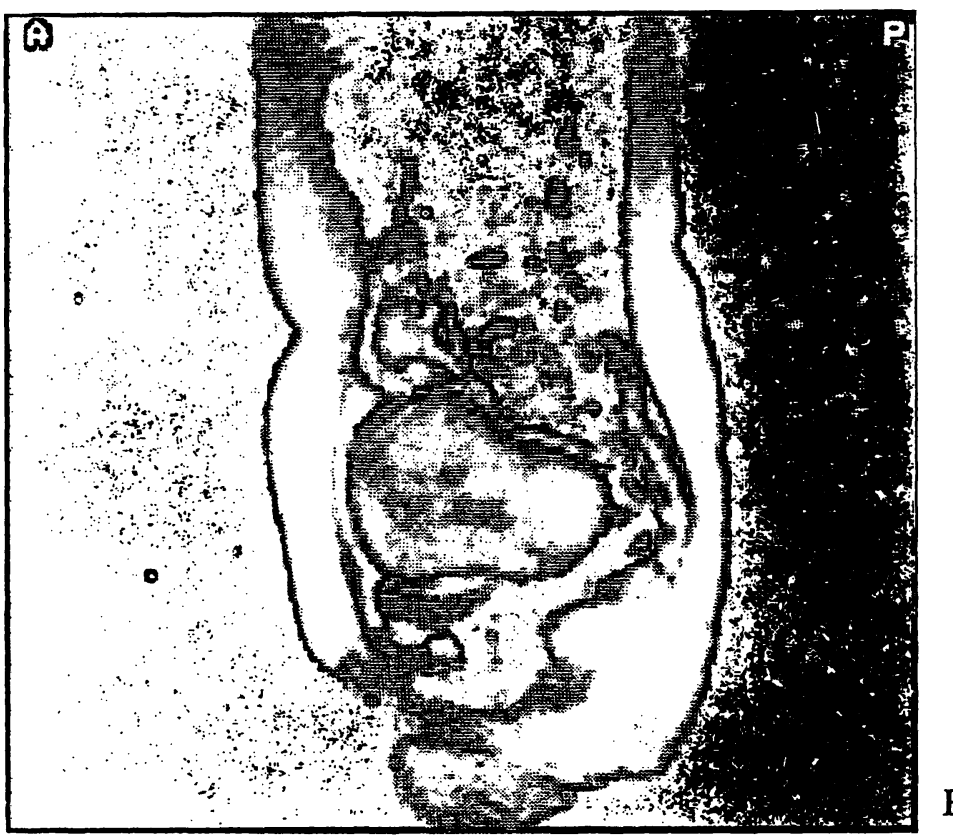

Fig. 1. A) $T_{1}$ B) Inversion recovery C) Proton density. Sagittal section, 20 week fetus, cephalic presentation. Anterior placenta. Proton density image gives the best anatomical detail. 
In the first and second trimesters of pregnancy the fetus is best demonstrated on the proton density and D images (Fig. 1C). It is not well seen in the $T_{1}$ and inversion recovery images due to the presence of the relatively large volume of amniotic fluid, which has a long relaxation time and appears very similar to that of the fetus and placenta (Fig. 1A, B). The fetus, placenta and uterus are well seen in the proton density and $\mathrm{D}$ images. The placental site is easily localized (Figs. 1 and 2) even when situated posteriorly as shown in Figure 2. After 26 weeks there is an improvement in the quality of the fetal images and fetal organs are recognizable. The poor detail which occurs when excessive fetal movement occurs was commonly encountered at early gestations while after 26 weeks the relative decrease in amniotic fluid minimized movement and the effect of amniotic fluid on the fetal detail on the $T_{1}$ and inversion recovery images (Figs. 3 and 4). In the third trimester identification of the fetal brain, lungs, heart, liver, bowel, bladder, limbs and umbilical cord is possible. It has been found that for the best examination after about 22 weeks the patient should have sagittal imaging lying supine (one midline section is usually adequate to demonstrate fetal lie and placental site), fol-

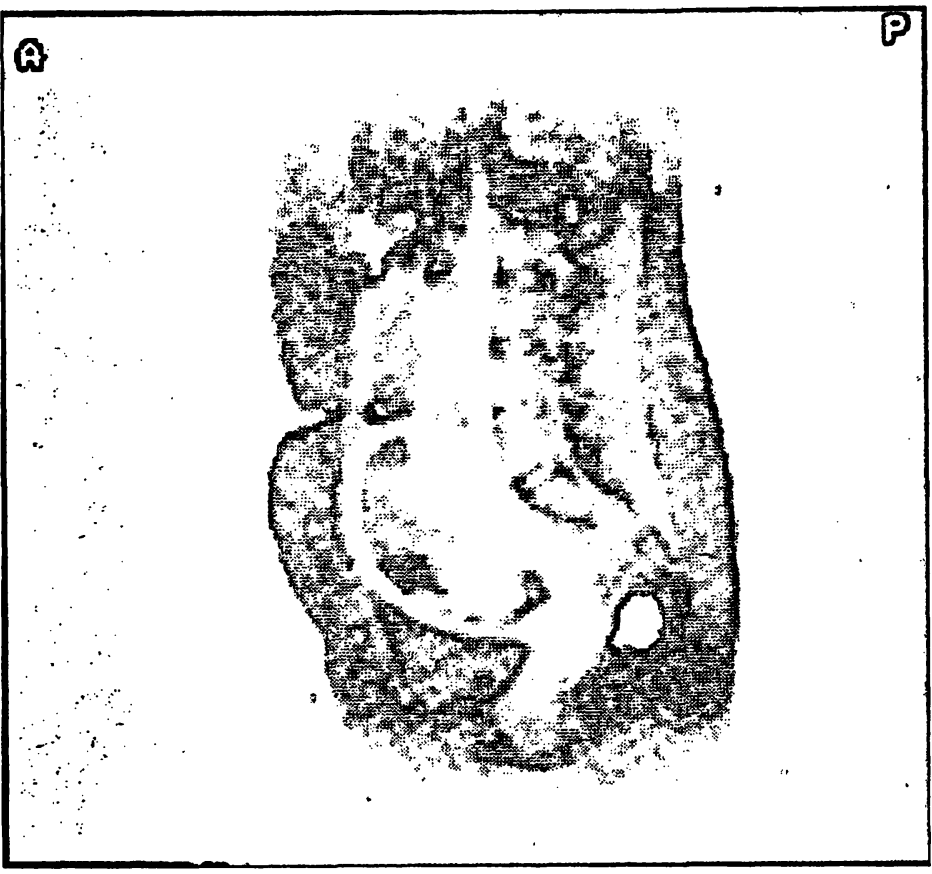

Fig. 2. Proton density image, sagittal section 18 week gestation fetus, the placenta lies posteriorly. The maternal bladder is seen below the uterus. The vagina and rectum are also well demonstrated.

lowed by axial position most patients feel more comfortable and lie quietly with the result that the fetus often settles down and does not move about so much, resulting in better images.
A

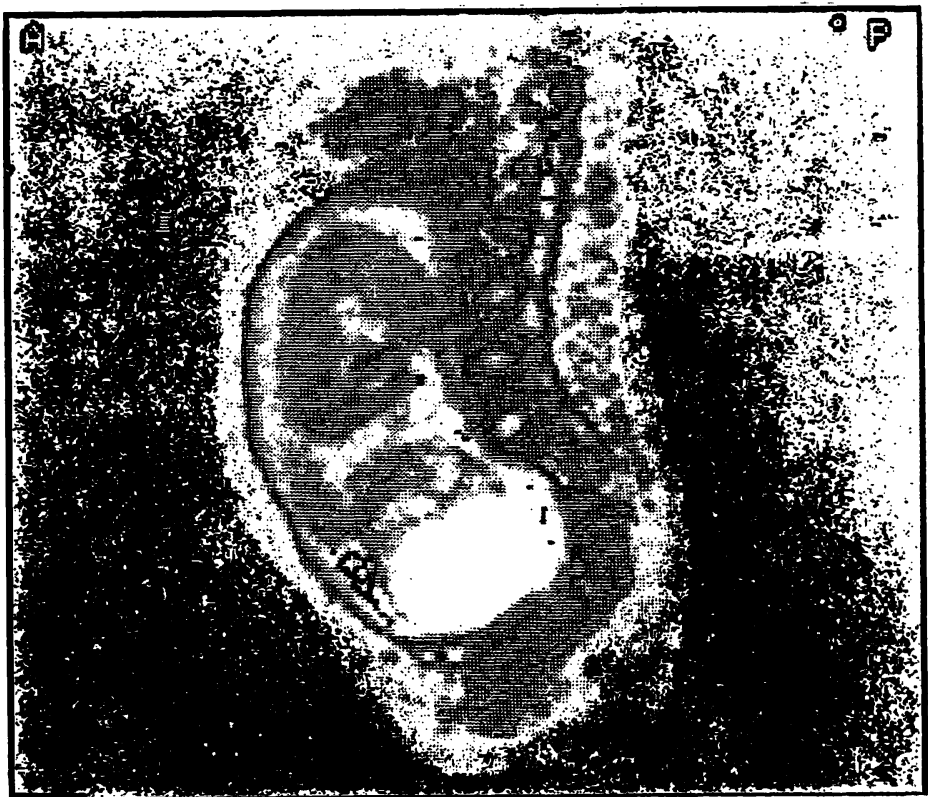

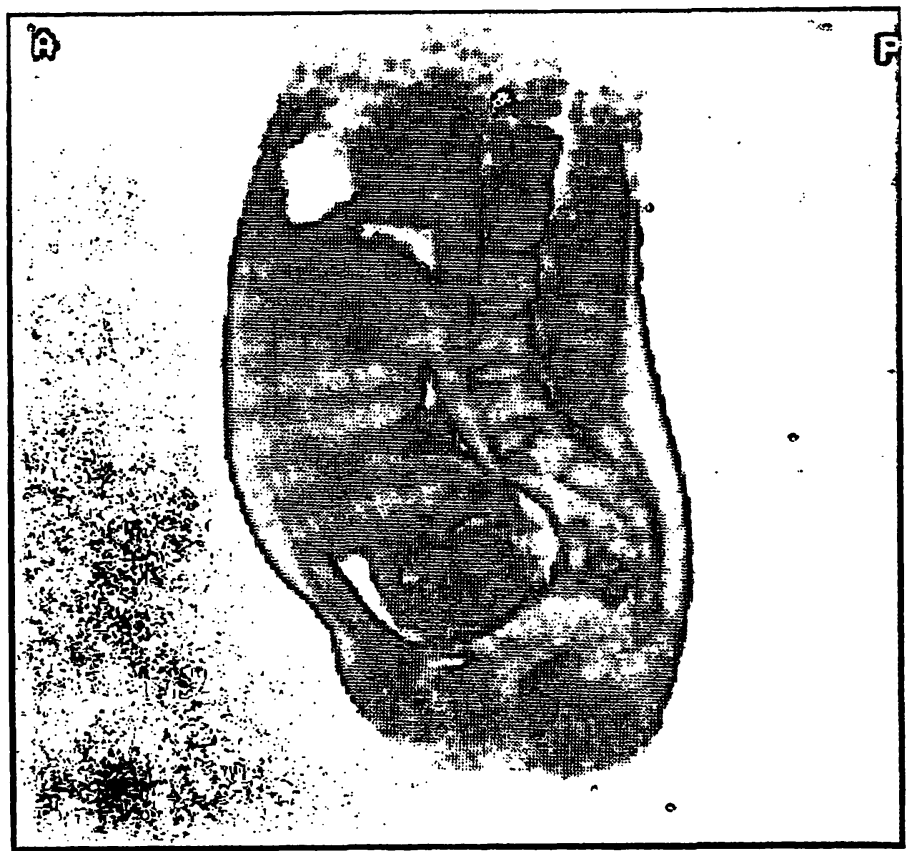

Fig. 3. A) $T_{1}$ B) Proton density. Sagittal section 28 weeks gestation, normal fetus showing fetal brain, orbits, lungs, liver and bladder. Anterior placenta. 

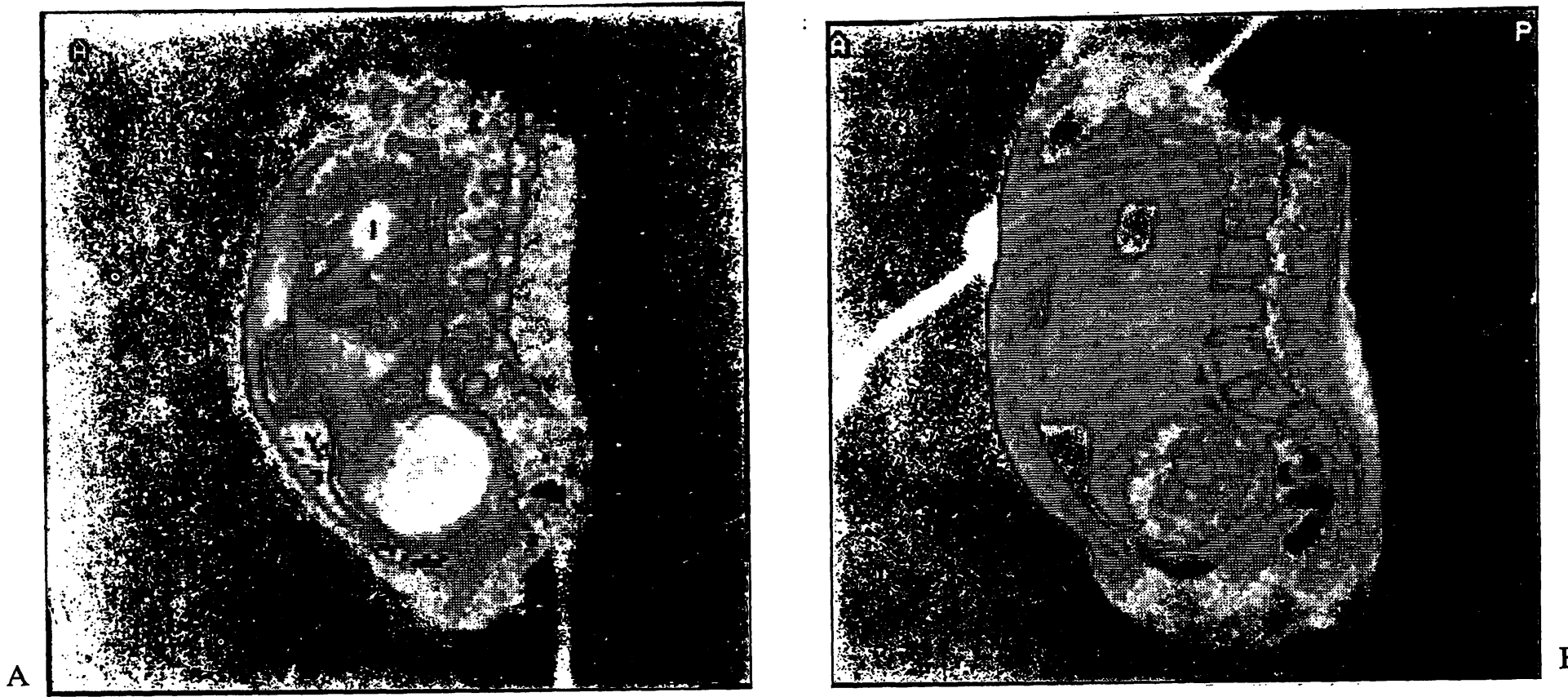

Fig. 4. A) $T_{1}$ B) Proton density. Sagittal section of same fetus as in Figure 3, but at 34 weeks and demonstrating the same features.

Measurements of $T_{1}$ for various maternal and fetal tissues showed considerable variation which sometimes correlated with the stage of pregnancy. For example, $T_{1}$ of cervix progressively increases with advancing pregnancy and may reflect the increasing water content of the cervix during pregnancy. Conversely $T_{1}$ of fetal brain decreases from midpregnancy $(900 \mathrm{~ms})$ till term $(600 \mathrm{~ms})$ and this fall has been found to continue after delivery. This fall in $T_{1}$ continues until the adult levels $(225-300 \mathrm{~ms})$ are reached [8] reflecting myelination of the central nervous system.

The long relaxation time of developing brain shows as a very white almost featureless organ on the $T_{1}$ image. However the presence of myelination in the basal ganglia is shown by a decrease in $T_{1}$ appearing light grey. The proton density image however gives more anatomic detail and is useful for studying the gross morphology of the brain (Fig. 5).

Fetal fat when present is easily identified and its thickness may be measured accurately after 32 weeks. Because of the short $T_{1}$ relaxation time of fat, which is due to the large amount of closely bound hydrogen protons in fat, it is well visualised on the $T_{1}$ and inversion recovery images (Fig. 6), appearing almost black on $T_{1}$ images and white on inversion recovery. In the study of pregnancy in patients with diabetes mellitus, measurement of the fetal fat thickness may be useful for determining the optimum time for delivery.

Other fetal organs are also well displayed and may be observed. Fetal lungs, presumably because of the fluid in them, give a strong signal appearing white in the $T_{1}$ image (Fig. 7A) and black on proton density (Figs. 7B and 8 ). The fetal liver appears dark grey on $T_{1}$ images (Figs. $3,4,9,10)$ and when the $T_{1}$ is measured it becomes shorter as gestation increases. Before 25 weeks the $T_{1}$ of liver measures $500-450$ msec, between $25-35$ weeks it is in the range $400-300 \mathrm{msec}$ and after 35 weeks is between $225-250 \mathrm{msec}$. The kidneys appear light grey/ white due to the strong signal from blood and urine in $T_{1}$ images (Fig. 9). The bladder similarly is seen when full of fluid as a white hollow viscus in the pelvis (Figs. 3 and 4). This ability to demonstrate the urinary bladder is of significance when examining cases of oligo- 

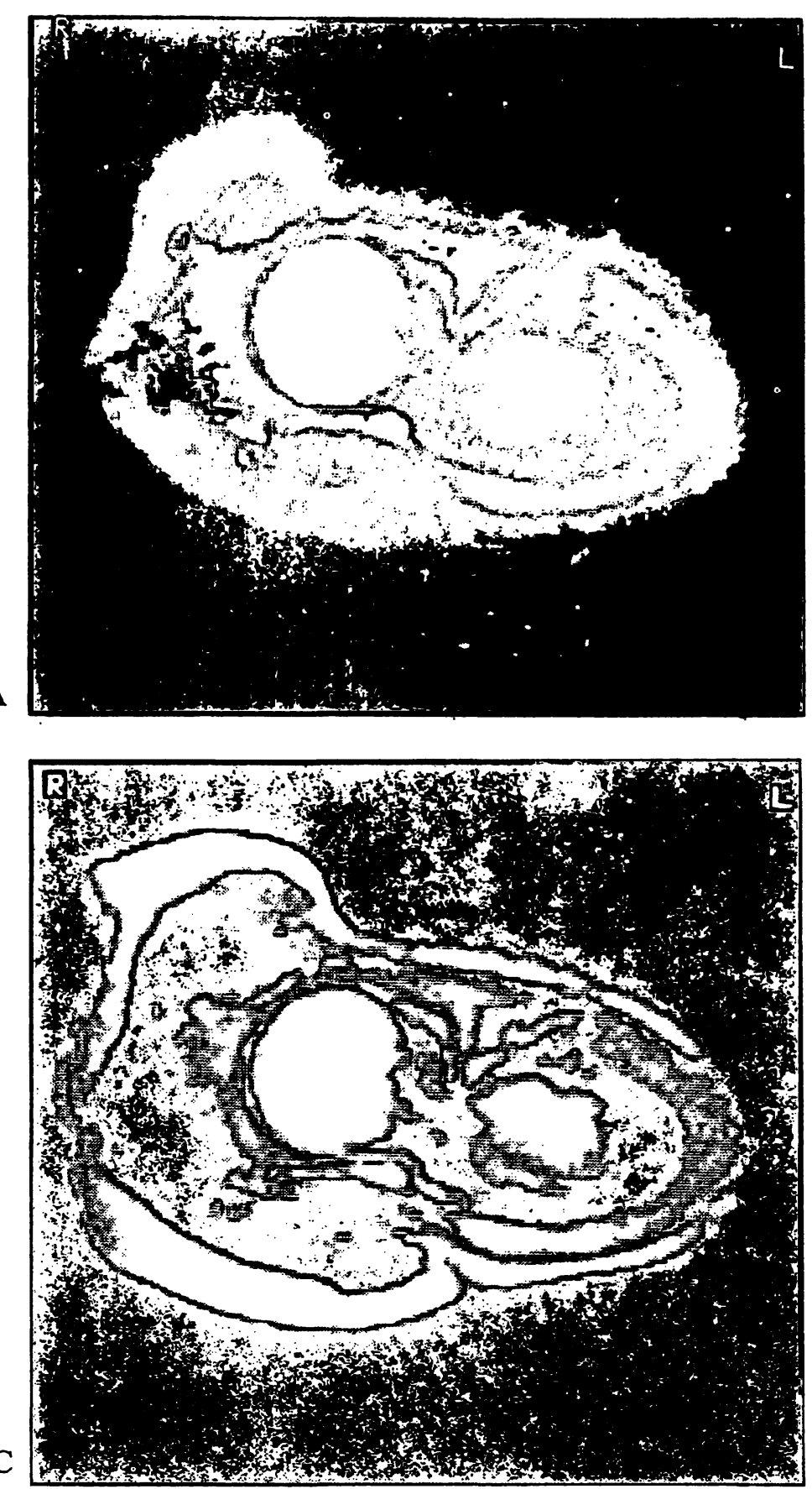

hydramnios, where demonstration of the bladder containing fluid will indicate good renal function (Fig. 10).

\section{Discussion}

The demonstration of fetal soft tissues by a safe non-ionizing imaging technique opens up a new method for studying both fetal development

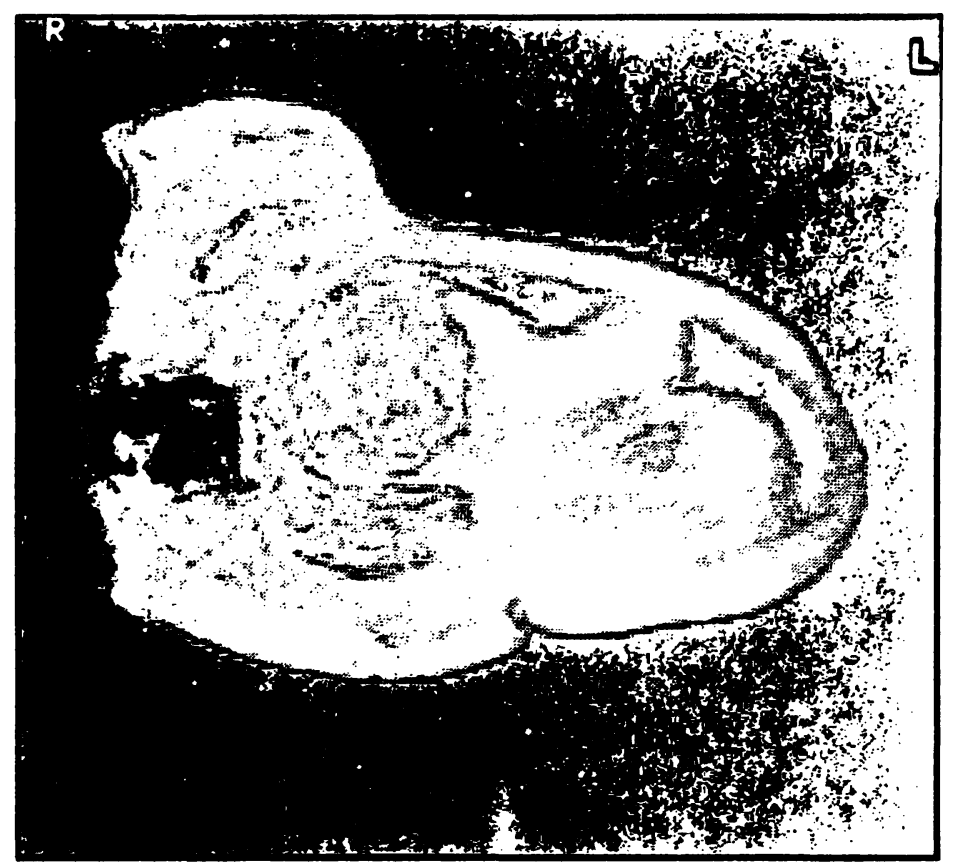

B

Fig. 5. A) $T_{1}$ B) Inversion recovery C) Protein density. Axial section with patient lying on her left side. Oblique section of 36 week normal fetus demonstrating fetal brain, buccal fat pad and lungs.

and maternal physiology. Whilst it is not suggested that NMR imaging should replace ultrasound for routine examination, it will be useful for placental localization in difficult cases and for the more detailed examination of fetal abnormality initially displayed by ultrasound.

The clear demonstration of the maternal bone anatomy suggests that NMR could replace Xray techniques for pelvimetry. 

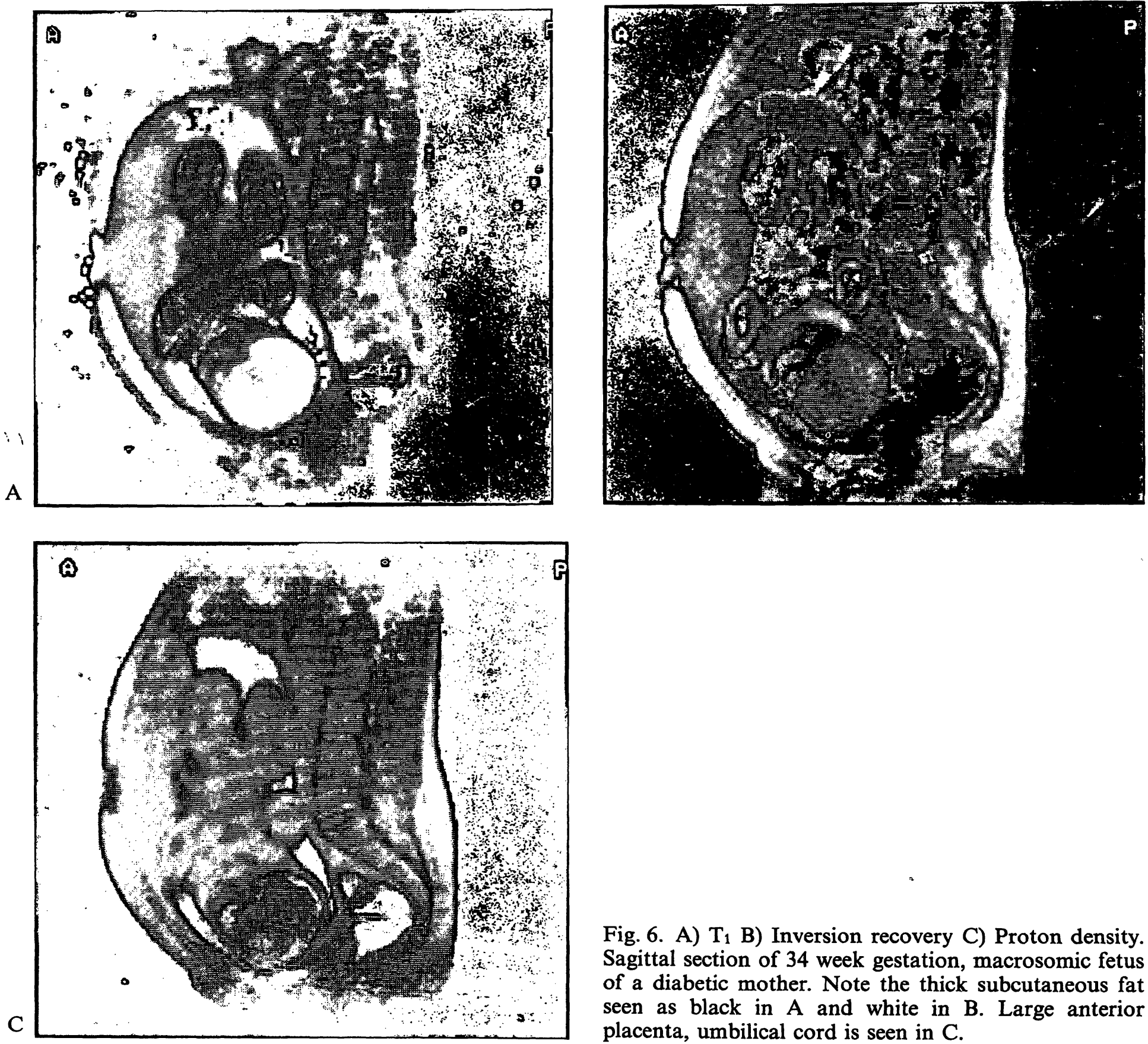

Fig. 6. A) $T_{1}$ B) Inversion recovery C) Proton density. Sagittal section of 34 week gestation, macrosomic fetus of a diabetic mother. Note the thick subcutaneous fat seen as black in A and white in B. Large anterior placenta, umbilical cord is seen in C.

Much further work has to be done, making specific $T_{1}$ observations of fetal organs before the technique can be applied to the study of fetal development. However these initial observations indicate that NMR imaging is useful in the study of patients with oligohydramnios

and those with diabetes mellitus, in whom measurement of fetal and uterine size together with measurement of the fetal subcutaneous fat thickness is useful in deciding gestational age and planning delivery. 

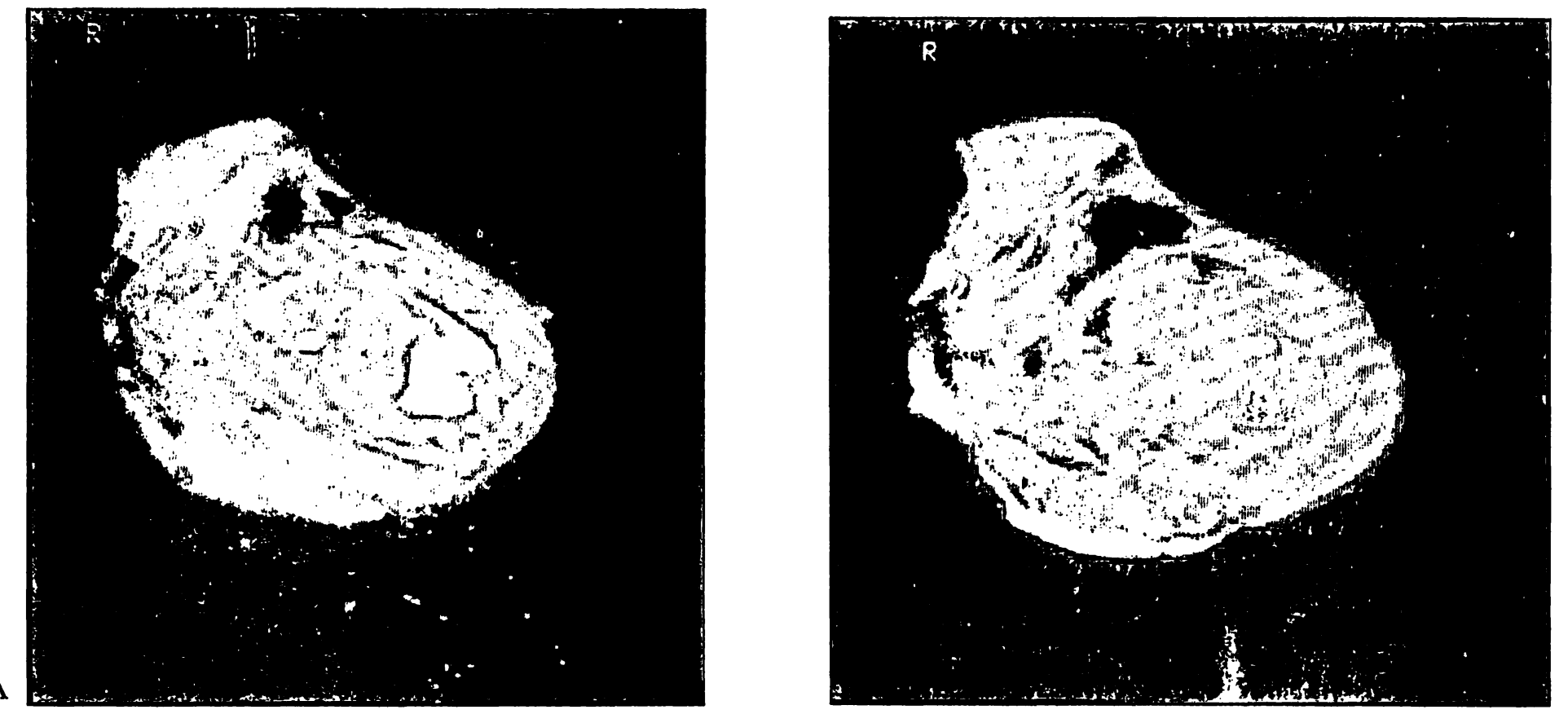

B

Fig. 7. A) $T_{1}$ B) Proton density. Axial section, mother lying on her left side resulting in oblique view of the chest of a 34 weeks fetus. Lungs appear white in A and black in B. The heart is seen clearly as is the spinal canal in upper dorsal region.

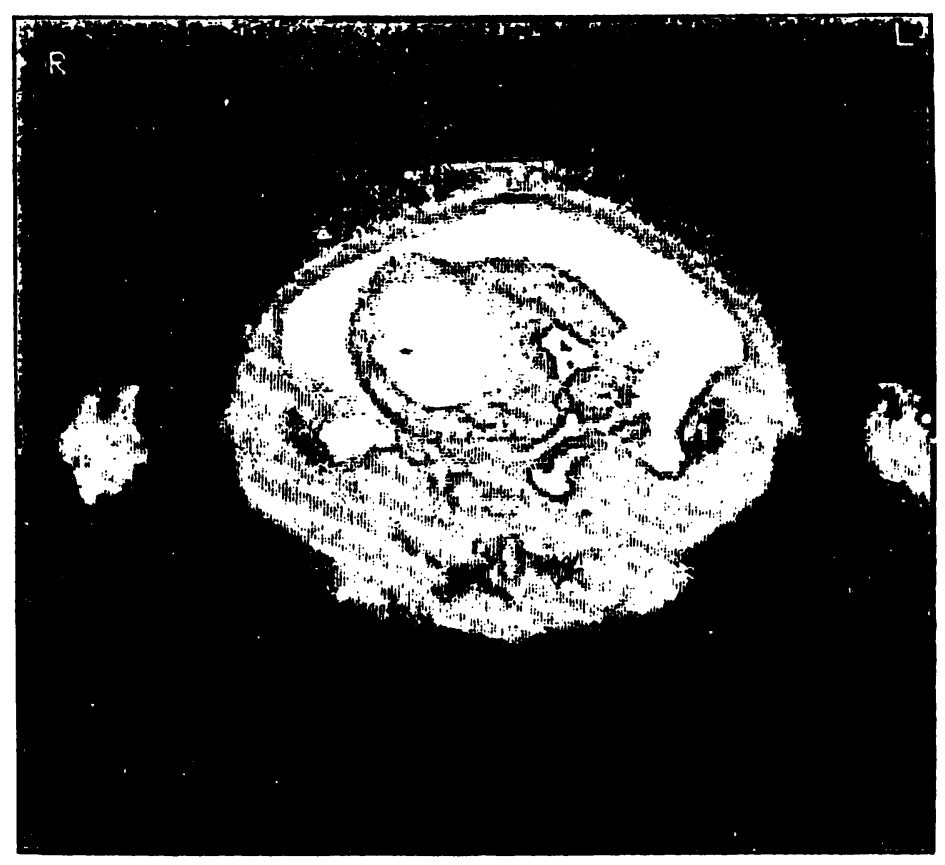

Fig. 8. $T_{1}$ axial section through thorax of 36 weeks gestation fetus. Lungs (white), liver (light grey), spinal canal (white) and fat around thorax and arms (dark grey) clearly seen.

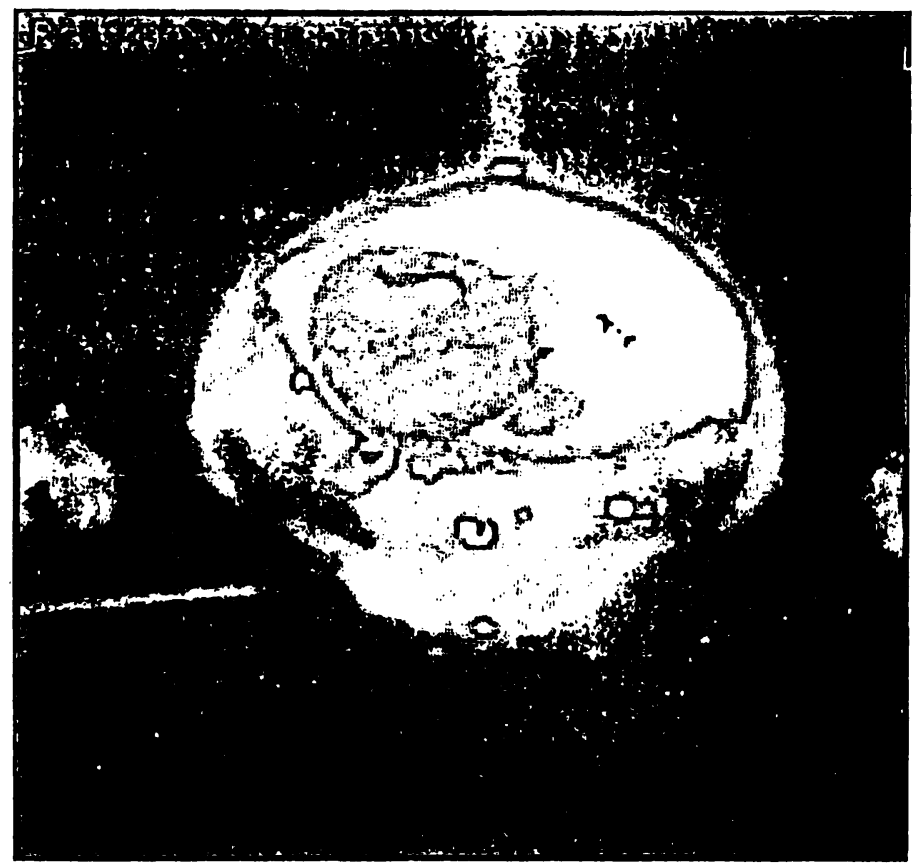

Fig. 9. $T_{1}$ axial section through abdomen of 36 week gestation fetus. Liver appears darker grey than the surrounding muscle and the portal vein can be seen within it. The spinal canal appears white as does the left kidney and stomach lying above the liver in this image. 

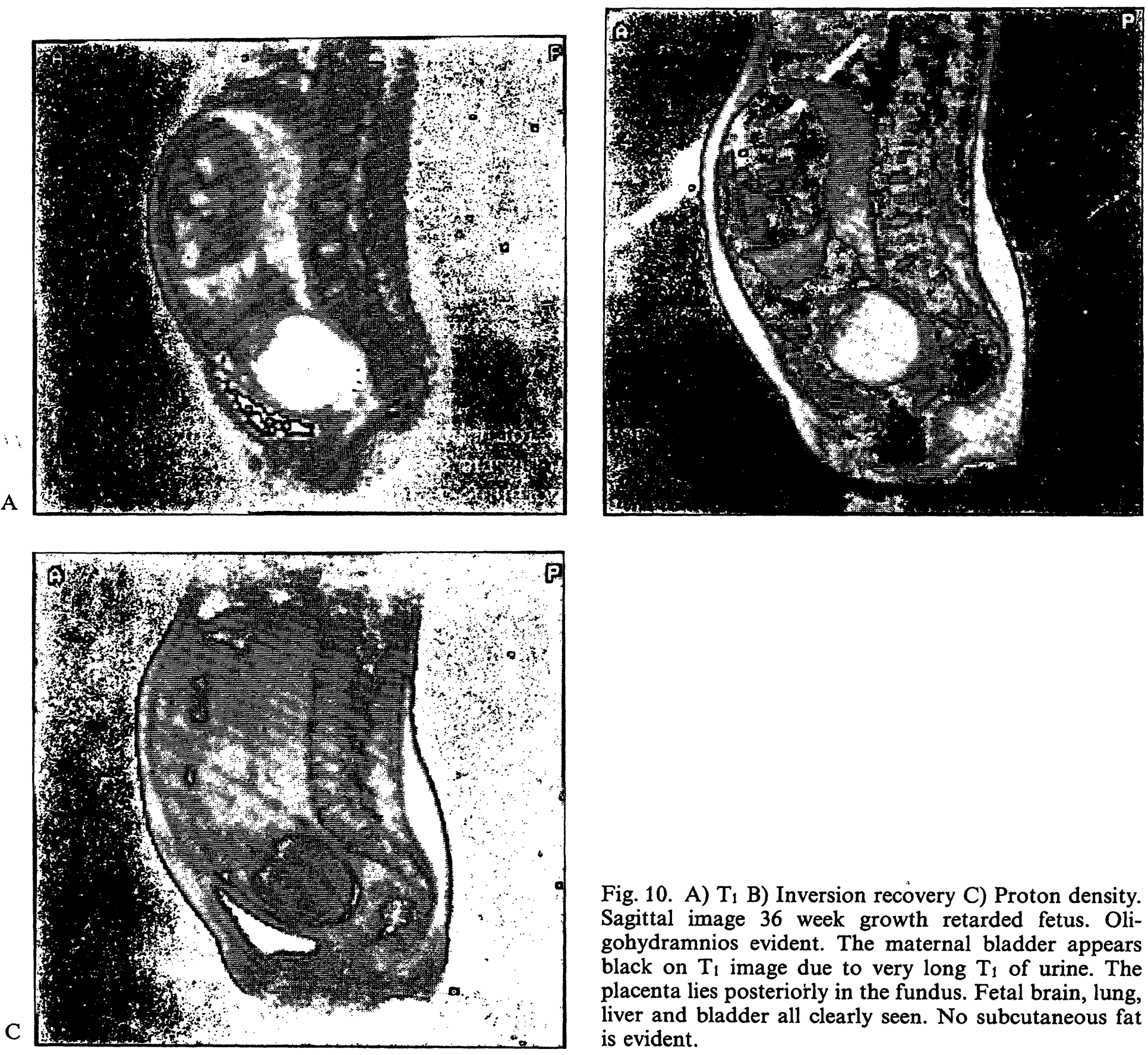

Fig. 10. A) $\left.T_{1} B\right)$ Inversion recovery C) Proton density. Sagittal image 36 week growth retarded fetus. Oligohydramnios evident. The maternal bladder appears black on $T_{1}$ image due to very long $T_{1}$ of urine. The placenta lies posteriorly in the fundus. Fetal brain, lung, liver and bladder all clearly seen. No subcutaneous fat is evident.

Acknowledgements: I am indebted to Professor J. R. Mallard and Dr. J. M. S. Hutchison and their team of physicists at the University of Aberdeen for the development of the NMR imager used to examine the patients whose images illustrate this paper. I should like to thank Professor I. G. MACGILlivRAY of the Department of Obstetrics, University of Aberdeen, for his advice and encouragement and Drs. H. SUTHERLAND and D. AMBRAMOvich for allowing me to study patients under their care.

\section{Summary}

Nuclear magnetic resonance (NMR) imaging is a new technique for in-vivo human imaging. The technique does not use ionizing radiation but employs a radiofrequency pulse and a strong magnetic field to map

the hydrogen proton distribution in the body. Since most of the hydrogen in the body is present in either water or fat it is the best imaging method yet devised for displaying the soft tissues of the body. The principles 
of NMR imaging are briefly described in simple terms for the benefit of the reader not yet familiar with the technique before discussing its potential use in the study of the developing fetus.

The absence of ionizing radiation together with the good resolution soft tissue images allow for accurate demonstration of the uterus, placenta and fetus in the pregnant patient. Prior to 22 weeks gestation the fetus may be difficult to image due to its movement during imaging. After 26 weeks the fetus is generally well demonstrated and measurements of fetal size easily made. Observations of the fetal brain, lungs, heart, liver and genito-urinary tract are possible and by measuring the strength of the NMR signal the development of these fetal organs may be made. In the fetus of the diabetic mother measurement of the fetal subcutaneous fat is possible and may be of use in assessing gestational age.

The placenta is easily localized even when situated posteriorly. Observations of maternal organs are also possible, especially the kidneys and spine.

Keywords: Nuclear magnetic resonance imaging, NMR, obstetrics, pregnancy.

\section{Zusammenfassung}

\section{Einsatz der Kernspintomographie während der Schwan- gerschaft}

Die Kernspintomographie (NMR) ist ein neues Verfahren zur in-vivo-Darstellung beim Menschen. Es wird keine ionisierende Strahlung eingesetzt, sondern mit Hilfe eines Radiofrequenzimpulses und eines Magnetfeldes die Verteilung der Wasserstoffprotonen im Körper aufgezeichnet. Da sich die größten Mengen an Wasserstoff in Wasser oder Fett befinden, ist die Kernspintomographie das beste bildgebende Verfahren zur Weichteildarstellung. Für den Leser, der mit der Technik noch nicht vertraut ist, wird das Prinzip der Kernspintomographic mit einfachen Begriffen kurz beschrieben; anschließend wird der mögliche Einsatz bei Untersuchungen am Feten diskutiert.

$\mathrm{Da}$ auf ionisierende Strahlung verzichtet wird und Weichteilbilder mit guter Auflösung möglich sind, kön- nen Uterus, Plazenta und Fet bei der schwangeren Frau genau dargestellt werden. Vor der 22. Schwangerschaftswoche kann die Darstellung des Feten wegen der starken Kindsbewegungen Schwierigkeiten bereiten; nach der 26. Woche erhält man gute Bilder vom Feten, wobei auch Größenbestimmungen leicht erfolgen können. Untersuchungen am fetalen Gehirn, Lungen, Herz, Leber und Urogenitalsystem sind möglich; die Verstärkung des NMR-Signals läßt dabei Rückschlüsse auf die Entwicklung der fetalen Organe zu. Bei Feten diabetischer Mütter ist die Messung der subcutanen Fettschicht möglich; dies kann bei der Bestimmung des Gestationsalters nützlich sein.

Auch bei Hinterwandsitz läßt sich die Plazenta gut lokalisieren. Untersuchungen der mütterlichen Organe, speziell der Nieren und der Wirbelsäule, sind ebenfalls möglich.

Schlüsselwörter: Geburtshilfe, Kernspintomographie, NMR, Schwangerschaft.

\section{Résumé}

Utilisation potentielle de l'imagerie de la résonance magnétique nucléaire au cours de la grossesse

La résonance magnétique nucléaire $(\mathrm{RMN})$ est une nouvelle technique de visualisation humaine in vivo. Cette technique n'utilise pas de radiations ionisantes mais $\mathrm{cm}$ ploie un pulse de radio-fréquence et un champ magnétique puissant pour dresser la carte de la distribution des protons hydrogène dans le corps. Comme la majeure partie de l'hydrogène du corps se trouve dans. l'eau et dans la graisse, c'est la meilleure méthode de visualisation pour exposer les tissus mous de l'organisme. Les principes de l'imagerie en RMN sont brièvement décrits en termes simples pour le profit du lecteur pas encore familiarisé avec cette technique, ensuite on discute son utilisation potentielle pour l'étude du fotus en croissance.

L'absence de radiations ionisantes jointe au bon pouvoir de résolution pour les images des tissus mous permet une étude appropriée de l'utérus, du placenta et du fotus chez la femme enceinte. Avant la 22ème semaine, il peut être difficule de visualiser le fœtus en raison de ses mouvements pendant l'examen. Après la 26ème semaine, on voit généralement bien le foetus et on peut aisément mesurer la taille du fetus. Il est possible d'observer le cerveau, les poumons, le cœur, le foic et l'appareil génitourinaire du fetus; également, en mesurant la force du signal RMN on peut apprécier le développement de ces organes fœtaux. Chez le fœtus de mère diabétique, il est possible de mesurer la graisse sous-cutanée et cela peut être réalisé pour apprécier l'âge gestationel.

On peut aisément localiser le placenta même lorsqu'il est inséré en arrièrc. Il est également possible d'observer les organes de la mère, tout particulièrement les reins et la colonne vertébrale.

Mots-clés: Grossesse, imagerie, obstétrique, résonance magnétique nucléaire, RMN. 


\section{Bibliography}

[1] Bydder, G. M., R. E. Steiner, I. R. Young, A. S. Hall, D. J. Thomas, J. Marshall, C. A. Pallis, N. M. LEGG: Clinical NMR imaging of the brain: 140 cases. Am. J. Roentgenol. 139 (1982) 215

[2] COOKE, P., P. G. MorRIS: The effects of NMR exposure on living organisms. II. A genetic study of human lymphocytes. Br. J. Radiol. 54 (1981) 622

[3] Edelstern, W. A., J. M. S. HutChison, G. Johnson, T. W. REDPATH: Spin-warp NMR Imaging and applications to human wholebody imaging. Phys. Med. Biol. 25 (1980) 751

[4] Edelstein, W. A., J. M. S. Hutchison, F. W. Smith, J. R. Mallard, G. Johnson, T. W. Redpath: Human whole-body NMR tomographic imaging: Normal sections, Br. J. Radiol. 54 (1981) 149

[5] Foster, M. A., C. H. KNight, J. E. Rimmington, J. R. MALlARD: Fetal imaging by NMR: A study in goats. Radiology 149 (1983) 193

[6] Hutchison, J. M. S., W. A. Edelstern, G. Johnson: A whole-body NMR imaging machine. J. Phys. [E] 13 (1980) 947

[7] Johnson, I. R., E. M. Symonds, D. M. Kean, B. S. Worthington, F. Broughton-Pipkin, R. C. HAWKES, M. GYNGELL: Imaging the pregnant human uterus with nuclear magnetic resonance. Am. J. Obstet. Gynecol. 148 (1984) 1136

[8] LeVene, M. I., A. Whitelaw, V. Dubowitz, G. M. Bydder, R. E. Steiner, C. P. Randall, I. R. YouNG: Nuclear Magnetic Resonance imaging of the brain in children. Br. Med. J. 285 (1982) 774

[9] PykeTt, I. L.: NMR imaging in medicine. Sci. Am. 246 (1982) 78

[10] Pykett, I. L., J. H. Newhouse, F. S. Buonanno, T. J. Brady, M. R. Goldman, J. P. Kistler, G. M. PoHost: Principles of nuclear magnetic resonance imaging. Radiology 143 (1982) 157

[11] SMITH, F. W.: The potential role of NMR imaging in pediatric practice. Pediatr. Radiol. 13 (1983) 141

[12] Smith, F. W., J. M. S. Hutchison, J. R. Mallard, G. Johnson, T. W. Redpath, R. D. Selbie, A. ReID, C. C. SMITH: Oesophageal carcinoma demonstrated by whole-body nuclear magnetic resonance imaging. Br. Med. J. 282 (1981) 510

[13] Smith, F. W., J. R. Mallard, J. M. S. Hutchison, A. ReID, G. Johnson, T. W. Redpath, R. D. SelbIE: Clinical application of nuclear magnetic resonance. Lancet 1 (1981) 78

[14] Smith, F. W., J. R. Mallard, A. Reid, J. M. S. Hutchuson: Nuclear magnetic resonance tomographic imaging in liver disease. Lancet 1 (1981) 963

[15] Smith, F. W., A. ReID, J. R. Mallard, J. M. S. HutchisON: Nuclear Magnetic Resonance imaging of the pancreas. Radiology 142 (1982) 677

[16] Smith, F. W., A. M. Apam, W. D. P. Phillips: NMR Imaging in pregnancy. Lancet 1 (1983) 61

[17] Smith, F. W., F. MaclenNan, D. R. Abramovich, I. MACGILlivRAY, J. M. S. HUTCHISON: NMR imaging in human pregnancy: A preliminary study. Mag. Res. Imag. 2 (1984) 57

[18] STark, D. D., S. M. MCCarthy, R. A. Filly, P. W. Callen, H. HricaK, C. B. Higgins: Obstetrical Magnetic Resonance Imaging. Proceedings of 3rd Annual Meeting; Society of Magnetic Resonance in Medicine, p. 700, New York 1984

[19] ThE NATIONAL RADIOLOGICAL PROTECTION BOARD AD HOC ADVISORY GROUP ON NUCLEAR MAGNETIC RESONANCE CLINICAL IMAGINE: Revised guidance on acceptable limits of eyposure during nuclear magnetic resonance clinical imaging. Br. J. Radiol. 56 (1983) 974

[20] Thomas, A., P. G. Morris: The effect of NMR exposure on living organisms. I. A microbial assay. Br. J. Radiol. 54 (1981) 615

Received January 21, 1985. Accepted January 30, 1985.

Francis W. Smith, M. D.

Department of Nuclear Medicine

Aberdeen Royal Infirmary

Foresterhill

Aberdeen, AB9 2ZB

Scotland, U. K. 